not have been styled cycadean. The differences between the reproductive organs of the recent and extinct forms find expression in the reference of the Jurassic and Lower Cretaceous plants to a separate group, Bennettitales, the existing cycadean genera being included in the Cycadales.

Dr. Marie C. Stopes has recently made two important contributions to our knowledge of the Bennettitales in a paper published in vol. ccviii. of the Philosophical Transactions of the Royal Society, containing descriptions and many admirable illustrations of a new species of seminiferous cone and a conebearing stem. The new cone, named Bennettites albianus, was discovered in the Gault of Folkestone by Mr. G. C. Walton. A French specimen of Bennettites was described some years ago by Prof. Lignier from beds in Normandy, believed by him to belong to the Gault, but with that exception all Bennettitean cones are from Jurassic or Wealden strata. The preservation of the English species is unusually good; the type-specimen is a portion of the broad domical apex of a cone about $120 \mathrm{~mm}$. in diameter, containing several hundred seeds, many of them with embryos. In general plan it agrees with previously described Bennettites cones; each seed is closely invested by seven interseminal scales, with expanded and laterally confluent truncate apices, forming a strong protective covering to the surface of the "fruit." It is suggested that the lacunar tissue surrounding the stalks on which the erect exalbuminous seeds are borne, and the tubular cells of the arillus-like basal cup in which each seed is embedded, drew up and retained water like the water-storage tissue of a bog moss, thus keeping the interior of the fruit moist. It is pointed out in support of this ingenious view that the seeds are deficient in vascular-conducting tissue.

The careful and detailed investigation of the complex structure of the seeds does not afford support to the view advanced by some writers that the Bennettitean seed agrees closely with that of Gnetum, nor are any new facts brought to light which favour an alliance between Bennettites and the Angiosperms.

It is probable that the plant which bore the cone described by Dr. Stopes was one of the latest representatives of the Bennettitales; the habit and the anatomical characters of the vegetative organs were, in the main, retained by the Cycads as we know them to-day - a small group, for the most part tropical in their distribution, and probably of comparatively recent origin. On the other hand, it has yet to be shown that the complex reproductive shoots of Bennettites gave rise to any direct descendants.

The thorough examination by Dr. Stopes of the Lower Greensand stem named by Carruthers Bennettites maximus shows that it agrees anatomically with other species except in the absence of any undoubted secretory cells in the ground-tissue of the stem and leaf-bases. The abundance of thick-walled, pitted cells, or "transfusion elements," which physiologically may represent secretory cells, is a characteristic feature. The most important point made $t y$ the author is that Bennettites maximus bore bisporangiate cones similar to those described by Wieland from America, and differing from the apparently unisexual cones previously recorded from Britain.

a. C. Seward.

\section{EDUCATION AND SCIENCE IN THE CIVIL SERVICE ESTIMATES.}

THE Estimates for Civil Services for the year ending March 3I, I920, amount in Class IV. (Education, Science, and Art) to 4I,251,6rol. The following are among the Estimates :-

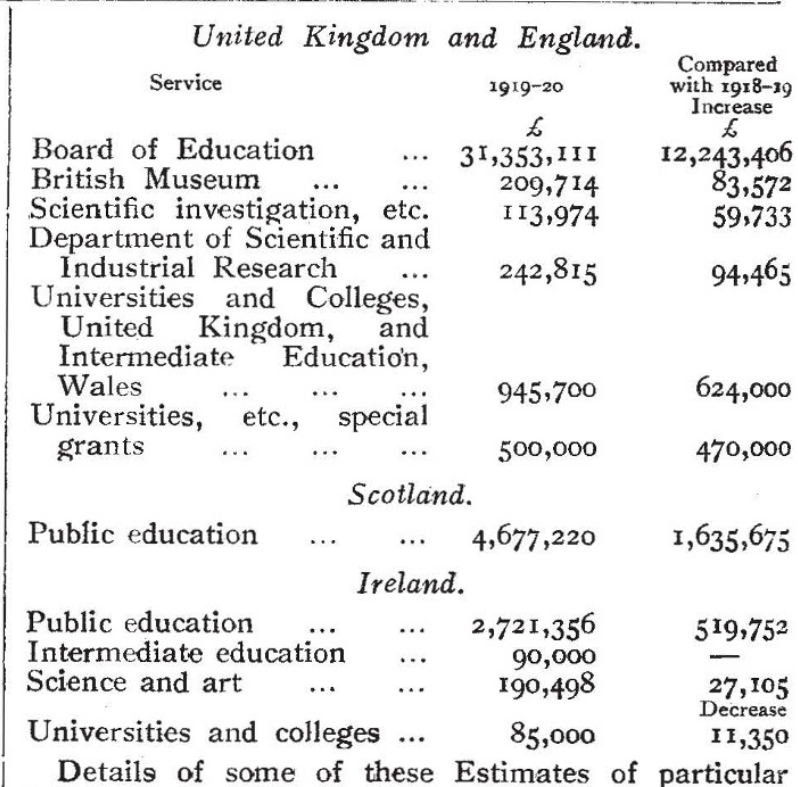

Details of some of these Estimates of particular interest to men of science are as follows :-

\section{Scientific Investigations, etc.}

Royal Society :

(i) Grant in aid of (a) scientific investigations undertaken with the sanction of a committee appointed for the purpose $(4000 l$.$) and (b)$ scientific publications (roool.) (ii) Grant in aid of salaries and other expenses of the Magnetic Observatory at Eskdalemuir $\quad \ldots \quad \ldots \quad \ldots \quad \ldots \quad \ldots \quad \ldots$ Meteorological Office Royal Geographical Society Marine Biological Association of the United I,250

Kingdom ... ... ... ... ... Scottish Meteorological Society $\begin{array}{llll}\cdots & \ldots & \ldots & \text { 100 }\end{array}$

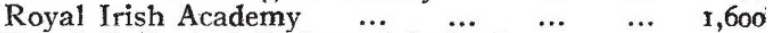

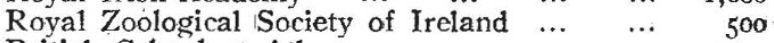
$\begin{array}{lllll}\text { British School at Athens } & \ldots & \ldots & \ldots & \text { 500 }\end{array}$ $\begin{array}{llllll}\text { British School at Rome } & \ldots & \ldots & \ldots & \ldots & 500\end{array}$ Royal Scottish Geographical Society $\ldots . \quad \ldots \quad 200$ $\begin{array}{lllll}\text { National Library of Wales } & \ldots & \ldots & \ldots & 8,90 n\end{array}$ National Museum of Wales:

Grant in aid of the expenses of the museum 4,000

$\begin{array}{lllll}\text { Special building grant in aid ... } & \ldots & \ldots & 20,000\end{array}$

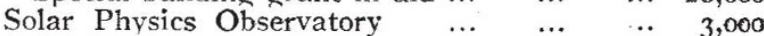

$\begin{array}{lllll}\text { School of Oriental Studies } & \ldots & \ldots & \ldots & 4,000\end{array}$

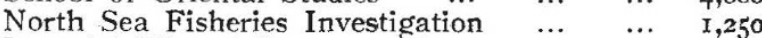
Imperial Mineral Resources Bureau $\ldots \quad \ldots \quad$... 11,000 $\begin{array}{llllll}\text { Edinburgh Observatory } & \ldots & \ldots & \ldots & \ldots & \mathrm{r}, 974\end{array}$

Scientific and Industrial Research.

Salaries, wages, and allowances $\quad \ldots \quad \ldots \quad$ ir,,$_{70}^{\hbar}$ Travelling and incidental expenses $\ldots \quad \ldots \quad$ r,500 Grants for Investigation and Research :

(I) Grants for investigations carried out by learned and scientific societies, etc. ...

(2) Grants for investigations directly controlled by the Department of Scientific and Industrial Research ... $\ldots . \ldots$

(3) Grants to students and other persons engaged in research $\quad . . \quad \ldots . \quad \ldots$ (These grants will be distributed by a Committee of the Privy Council, on the recommendation of an Advisory Council, to promote the development of scientific 
and industrial research in the United Kingdom, and will be subject to such conditions as the Committee may think necessary.)

Fuel Research Station ...
National Physical Laboratory

$\cdots \quad \cdots \quad 12,775$

Universities and Colleges, United Kingdom.

University of London ...

Victoria University of Manchester $\quad \ldots \quad$ …

\begin{tabular}{lllll} 
University of Birmingham $\ldots$ & $\ldots$ & $\ldots$ & 2,000 \\
\hline
\end{tabular}

$\begin{array}{llllll}\text { University of Wales } & \ldots & \ldots & \ldots & \ldots & \\ & & \ldots & \end{array}$

$\begin{array}{lllll}\text { University of Liverpool } & \ldots & \ldots & \ldots & 2 ; 000\end{array}$

$\begin{array}{llllll}\text { Leeds University } & \ldots & \ldots & \ldots, & \ldots & 2,000\end{array}$

$\begin{array}{llllll}\text { Sheffield University } & \ldots & \ldots & \ldots & \ldots & 2,000\end{array}$

$\begin{array}{llllll}\text { Bristol University } & \ldots & \ldots & \ldots & \ldots & 2,000\end{array}$

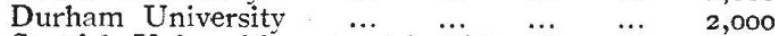

Scottish Universities, grant in aid under section 25 of the Universities (Scotland) Act, $1889,{ }^{2} 42,000 l$; additional grant in aid,

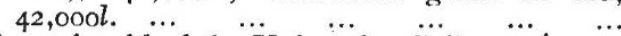

Grant in aid of the University Colleges Grants Deposit Account, to be employed in making grants in aid of certain Colleges in Great Britain giving education of a university standard in arts and sciences and technology

Grant in aid of the expenses of the $\dddot{\text { Univer- }}$ sity Colleges of North Wales, South Wales and Monmouthshire, and Aberystwyth (400ol. to each) ....

Additional grant in aid of the expenses of the University of Wales and of the University Colleges of North Wales, South Wales and Monmouthshire, and Aberystwyth (250ol., $5125 l$, $7750 l .$, and $5125 l$. respectively) ...

Grant in aid of the expences of the Imperial College of Science and Technology

Supplementary grant in aid of maintenance of Universities and Colleges in the United Kingdom

Total for Universities and Colleges ... $\overline{916,000}$ Spectal. Grants.


Certain of the universities, colleges, and other similar institutions which are in receipt of Parliamentary grants are in need of special assistance in order that they may, so far as possible, resume their full work under favourable conditions, and may not be hampered by extraordinary expenditure involved by the prolonged interruption of their activities and development caused by the war. The special grants in aid for I918-I9 were provided to meet particularly urgent cases in which some measure of assistance could not be delayed until the conclusion of hostilities without risk of grave permanent detriment to the institutions concerned.

: Services rendered without payment for other Government Departments are estimated as follows:-Admiralty, 6500l. : Air Ministry, 36,350l.; Ministry of Munitions, $63,000 l$.; War Office, $500 \%$. The testing fees at the National Physical Laboratory and charges for special investigations amounted to $26,500 l$.

2 In addition to an annual sum of $30,000 l$. payable to these Universities from the Local Taxation (Scotland) Account under Section 2 (2) of the Education and Local Taxaion Account (Scotland) Act, 1802.

$\$$ of this amount $60,000 l$. will be devoted to grants in aid of technological education.

4 This sum, together with $84,000 l$. provided in Class IV., 18 , is intended to raise to $1, \infty \infty, 000 l$. the total amount of the grants paid out of the Exchequer during the year 1919-20 for the maintenance of University Institutions in the United Kingdom.
Universities and Colleges, Ireland.

Queen's University of Belfast $\quad \ldots \quad \ldots . \quad 18,000$ $\begin{array}{lllll}\text { University College, Dublin } \quad \ldots & \ldots & \ldots & 32,000\end{array}$ $\begin{array}{lllll}\text { University College, Cork } & \ldots & \ldots & \ldots & 20,000\end{array}$ University College, Galway $\quad \ldots \quad \ldots \quad \ldots \quad$ I2,000.

National University of Ireland and University College. Dublin $\quad \ldots \quad \ldots . \quad \ldots . \quad \ldots$

Additional grant towards increasing the resources of University College, Galway $\ldots \quad$ 2,000

\section{UNIVERSITY AND EDUCATIONAL} INTELLIGENCE.

CAMBRIDGE.-The Cavendish professorship of experimental physics, recently vacated by the Master of Trinity, has been filled by the appointment of Sir Ernest Rutherford. This office carries with it the direction of the Cavendish Laboratory. An adequate continuation of the very remarkable line of occupants of this important position, represented by the names of Clerk Maxwell, Rayleigh, and J. J. Thomson, has thus been secured.

At the same time the University fortunately continues to be in a position to profit by the services of Sir J. J. Thomson on an honorary basis. A special professorship of physics without stipend has been created for him, and accommodation and resources will be provided, so far as finances permit, for the prosecution of his scientific work and his activities in the stimulation of research in physical science.

It is hoped that the University will very soon find itself in a position to embark upon the structural develonments which will be required in order to take full advantage of this great accession of strength in the most fundamental of the sciences, and to maintain the repute and activity of the Cavendish Laboratory at the level that the national interest in the coming time will more than ever demand.

London.--The Ramsay Memorial Committee has offered to the University a sum of not less than $25,000 l$. towards the foundation of a laboratory of chemical engineering at University College. The Senate has gratefully accepted the offer, and is allotting a site for the purpose.

$\mathrm{ON}_{\mathrm{N}}$ the iıvitation of the governors of Birkbeck College, London, Lord Haldane has accented the position of president of the college, in succession to the late Lord Alverstone.

Applications for grants from the Dixon Fund of the University of London for assisting scientific investigations must reach the Academic Registrar of the University before May I5 next.

THE Lindley studentship in physiology will shortly be awarded hy the University of London. It is open to students qualified to undertake research. Applications must be made to the Academic Registrar, the University of London, South Kensington, before April 30.

A committee of the Royal College of Physicians of London and of the Royal College of Surgeons of England will shortly appoint a Streatfeild research scholar in medicine and surgery. The annual value of the scholarship is about $25 \mathrm{ol}$., and the tenure three years, at the discretion of the committee. Applications, stating the nature of the proposed research, the place where it is to be carried out, and the status of the applicant, should be sent to the Registrar, Roval Collece of Phvsicians of London, Pall Mall East. S.W.r, marked "Streatfeild Scholarship."

Mr. Arthur Henderson, secretary of the Labour Party, appeals in the Times of April \& for a large and 